\title{
Improving the Environmental Work at University of Passo Fundo, Brazil - Towards an Environmental Management System
}

\section{Luciana Londero Brandli}

Architecture and Engineering Faculty at the Passo Fundo University (UPF), Passo Fundo, RS, Brazil

\section{Marcos Antonio Leite Frandoloso}

Architecture and Engineering Faculty at the Passo Fundo University (UPF), Passo Fundo, RS, Brazil

\section{Joel Tauchen}

Horizontina Faculty (FAHOR), Horizontina, RS, Brazil

\begin{abstract}
In the last few years, sustainable development and environmental management have become an important issue in Institutions of Higher Education (IHE). This paper aims to analyze the sustainable practices already implemented by the University of Passo Fundo (UPF), located in the Southern Brazil, and then, points out the guidelines for a sustainable environmental management, involving academic activities and the campus infrastructure. The analysis and diagnosis has been produced through the application of a methodology embedded in PDCA cycle, in order to verify on which way UPF has been facing such subjects. The basis of the proposal is a survey on national and international benchmarks with good practices of environmental sustainability at university campus Finally, are proposed some guidelines to review the environmental assessment process to following-up of the implementation of an own Environmental Management System. The research presents the conclusion that initiatives of sustainable principles have been adopted by several universities, but with an isolated approach, and the UPF the main problem is the absence of a consistent Environmental Policy that must concentrate these actions and efforts towards an effective EMS. Some actions are suggested to UPF for improved your EMS.
\end{abstract}

Keywords: Sustainable university, Environmental management system, Environmental planning, Practices, PDCA.

\section{Introduction}

The sustainable development is the target of discussion among different departments of civil and governmental societies at present. Following this tendency, the Higher Education Institutions (HEI) are also adapting themselves to this new thought, which demands a special attention to these environmental issues.

This way, the universities can collaborate with this new world perception from two main streams: the first one, is regarding the spread of suitable environmental 
practices among their students - that will multiply this learning between the communities where they will act at a later moment; the second one, are the actions that can be made by its own academic institution. The adoption of sustainable systems of environmental management in their installations is a first step that can be spread in action areas of HEI (Halac et al., 2005).

In this sense, the environmental education can be a key for the formation of an aware society and able to act at the control of aggravating circumstances in which the environment is in the current world. Therefore, it is this way that the universities assume the role of leaders at the indication of rational and appropriate solutions in the future. According to Brandli et al. (2008) it is the HEI responsibility to enable people who will be better prepared to make more correct decisions regarding these issues.

Corroborating these goals, different future meetings to the Tallories Declaration, in 1990 and Rio'92 have discussed strategies so that the universities, in a more extended scope of all society, can contribute in such an appropriate manner, to changes of paradigms towards the sustainable development, fact that becomes evident with the definition of UN for the "Decade of Education for the Sustainable Development” for 2005-2014 (UNESCO, 2005)

The University of Passo Fundo (UPF), as an example of university initiatives, has been developing actions for adaptation of structure of its campus for appropriate policies of environmental sustainability. The objective of this paper is to compile the sustainable practices already implemented by the University of Passo Fundo, and then, to point guidelines for a sustainable environmental management, involving academic and working activities of the campus structure. For this, was realized a survey on national and international benchmarks with good practices of environmental sustainability at university campus. The proposal was to present a systematization of procedures which is based on the known examples for to support the research at UPF.

\section{The Role of Institutions of Higher Education (IHE) at the Direction of a Sustainable Development}

Two roles are highlighted as major contributions from IHE to sustainable development:

I) The educational subject which is a fundamental practice in order to qualify professionals more involved in decision-making concerning environmental issues in the future.

II) The posture of some universities to implement EMS's at their university campuses presenting models and practical examples of sustainable management for society.

\section{Education for Sustainable Development}

The population growth, the uncontrollable consumption of natural resources and environmental degradation are demanding issues which need powerful and corrective actions. According to Mayor (1998), education is the key to sustainable and self-sufficient development. Education should be offered to all people in society, therefore everybody will have real chances to be educated throughout life. 
Environmental education, which is one of the bases for sustainable development, contributes to the fundamental comprehension of the relation and interaction between humanity and environment, promoting a public and environmental ethics concerning ecological equilibrium and quality of life, therefore people and organized social groups will realize the need to build their citizenship (Zitzke, 2002).

According to Halac et al. (2005), there are three fundamental fields of action: Research: a critical and methodological reflection on topics and methods linked to different sources of knowledge; Education and training: a process of searching knowledge and methods in different levels, interests and learning fields; Extension and dissemination: Research and Education passed through the multiple sectors of the community.

In general, IHE have an essential responsibility to qualify the new generations for a possible future. These institutions should conceive rational solutions based on reflection and basic research, and also should take the initiative to show possible alternatives and coherent proposals for the future (Fouto, 2002; Kraemer, 2004).

Kraemer (2004) and Tauchen (2006) emphasize that universities are highly qualified to be leaders of sustainable development. IHE whose purpose is to teach and qualify professionals more involved in decision-making, or citizens who are more qualified in it. These institutions have experience in the interdisciplinary investigation, and also have an essential role in the promotion of a project for sustainability.

Ferrer-Balas (2001) describes the experience at the Technical University of Catalonia, showing the role of university in society relating to sustainable development (Figure 1).

According to the model by Technical University of Catalonia, Fouto (2002) shows four levels of intervention in IHE:

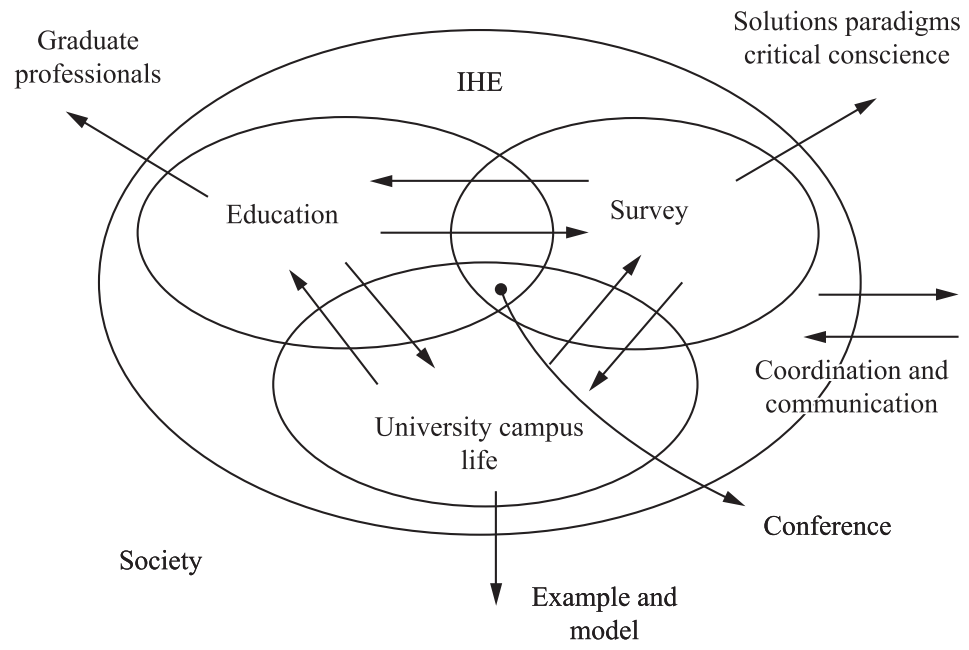

Figure 1. The role of university in society relating to the sustainable development (Ferrer-Balas, 2001, pp. 59). 
I) Education of professionals who are involved in decision-making concerning a sustainable future;

II) Investigation of solutions, paradigms and values for a sustainable society;

III) Operation of the university campuses showing models and practical examples of sustainability on the local scale;

IV) Coordination and communication between all the levels; and between all the levels and society.

To promote education and public conscience for Sustainable Development, the ideas from the articles of Rio/92 give special importance to the integration of the concepts of environment with development in all the educational programs. In particular, the analysis of the causes of problems concerning environment in a local context showing a specific objective was included on the AGENDA 21 (Almeida et al., 2008).

In spite of the fact that are different opinions about the barriers to adopt sustainable principles at universities, Leal Filho (2000) points out that even some authors considered the concepts "too abstract", "too broad", or "we have no personnel to look after it". There are many experiences showing what universities can do in order to achieve it, no matter what their characteristics, indicating the integration of sustainable approaches to solve problems.

\section{Posture and Practices of Sustainability in Institutions of Higher Education}

There are meaningful reasons to implement an EMS in an Institution of Higher Education, one of the reasons is that faculties and universities may be compared to small urban nucleus, involving several teaching, research and activities related to the operation such as restaurants, snack bars, accommodation, convenience centers, among other facilities. Besides, a campus needs basic infrastructure, water and energy supply system, sanitation system, pluvial water reservoir and access.

As a result of the activities related to the operation at the campus, there will be the solid waste and liquid effluents, consumption of natural resources, in other words the industrial vision concerning inputs and outputs. The Figure 2 shows the main flows at a university campus.

Bonnet et al. (2002) present a survey at the University of Bordeaux, France, with the purpose of to determinate the energy and water consumption from the available service in the institution. Relating to the consumption per capita of water, the result shows that it is higher compared to the average consumption in big cities; and relating to the consumption of energy, it is also similar to the consumption in the cities, showing the need to control this item.

According to Viebahn (2002) the University of Osnabruck, Germany, had proposed a systematic approach to reduce the consumption of resources at the university. The plan focuses on recording and modeling the material and energy flows of the University in order to develop an "ecobalance".

Figure 3 shows the representation of the system to control the inputs and outputs at the University of Bordeaux, emphasizing the relation among the consumption, campus area, number of people involved, and the resultant waste. 


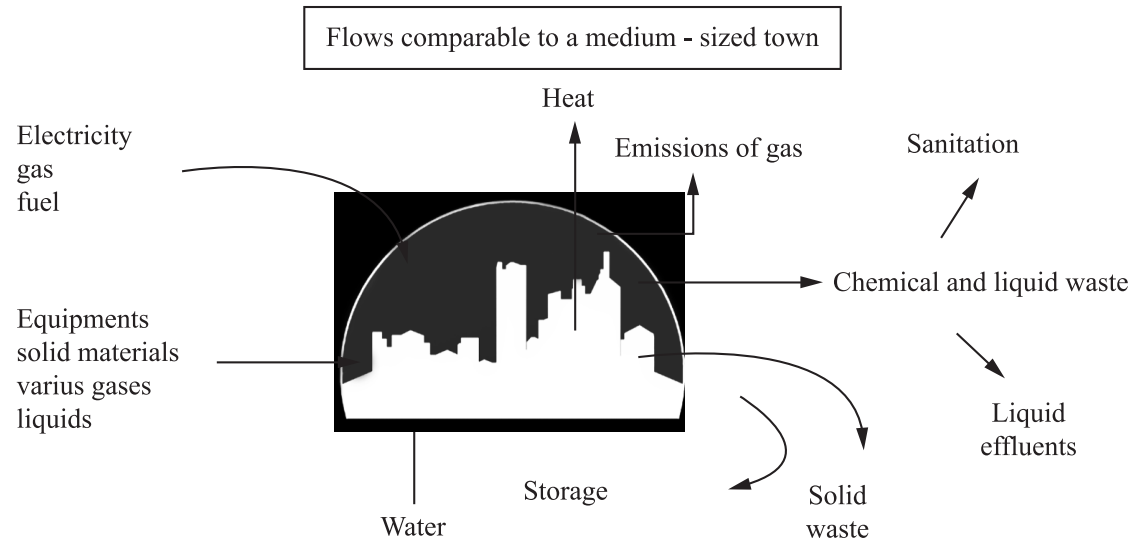

Figure 2. The main flows at a university campus (Careto and Vendeirinho, 2003, pp. 9).

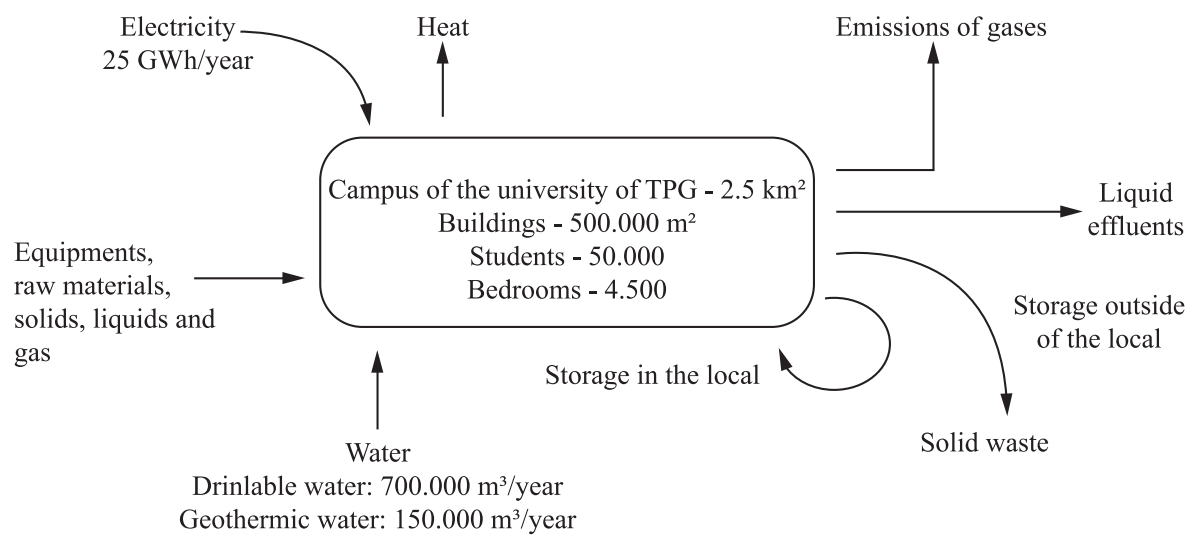

Figure 3. Energy and water flows at the campus of Bordeaux (Bonnet et al., 2002, pp. 15).

From these aspects it is evident that IHE should combat the resultant impacts in environment in order to become a model for other institutions in accordance with the legislation; and also should put theory into practice.

\section{Historical Overview of the Environmental Issues and IHE}

Universities started to introduce the environmental thematic in their management scheme in the 1960s. The new experiences appeared in the United States of America and, at the same time, there was a promotion for professionals of environmental science in the 1970s. In the 1980s, the major focus was the politics concerned with the waste management and efficiency relating to energy. During the 1990s, the environmental politics was developed on a global scale connecting a wide range of institutions, such as the Campus Ecology at the University of Wisconsin at Madison or the Brown is Green at the University of Brown in the United States of America (Delgado and Vélez, 2005).

The IHE were practically away from the debate on sustainable development, until the Conference in Rio de Janeiro in 1992. The experience brought the clear lesson 
that universities should accept the challenge because, if they do not involve in the solution of the emergent problems in global society, then universities will be ignored in the awakening of another engine of change. Therefore other institution or structure will be invited to promote leadership (International Association of Universities, 1993).

The period between the Conferences in Stockholm in 1972 and Rio de Janeiro in 1992, marked the emergence of institutions, partnerships and networks, which were engaged in (re)conduct IHE to the place that was reserved to them (Ecocampus, 1997).

In the Talloires Declaration (ULSF, 1990), in October 1990, principals and vice-principals of universities from many regions in the world showed their interest concerning the scale and speed of pollution and environmental degradation without precedent. These environmental changes threaten the survival of human beings, thousands of other species, the integrity of Earth and its biodiversity, the safety of the nations and the future generations. The Talloires Declaration, how it is called at the European campus in Talloires - France, concluded that it is fundamental to implement urgent actions in order to solve these problems and reverse the current tendencies.

In December 1991, a year later, in Halifax-Canada, representatives of the universities, linked to UNO and the association of universities and faculties in Canada, united with representatives of the universities from many countries, such as Brazil, Indonesia and Zimbabwe. The Halifax Declaration (1991) showed the disappointment concerning the disseminated and continuous degradation of environment, the unsustainable environmental practices, besides the perverse increase of poverty.

In August 1993, in the conclusion of the conference of the association of communitarian universities in Sweden, participants of 400 universities from 47 countries, focused on topics concerning people and environment. The issue was related to find ways how communitarian universities, leaders and students could link methodologies with their projects to accept the challenge of sustainability. The meeting in Sweden, inspired by the examples of Talloires and Halifax, and at the same time disappointed with the weak presence of universities in the Agenda 21, joined the appeal for a solution to stop environmental degradation and the increase of poverty worldwide. The participants expressed on The Swansea Declaration (1993) that the solutions to these problems will be efficient only if people recognize that all society is vulnerable, and that people all over the world need to use their strength and abilities in a positive and cooperative way.

In the Kyoto Declaration (1993) in Japan, 650 members of universities called out to: establish and spread a clear comprehension of sustainable development; use resources from the universities to promote a total comprehension of the danger - physical, biological and social - that affect the planet for government and the public; emphasize the ethical obligation of this generation to manage the practices of use of natural resources and known misuses which are at the root of environmental unsustainability; highlight the capacity of universities to teach and to follow the sustainable principles of development in research and action; and finally, feel motivated to review their own operations in order to reflect on the best sustainable practices of development.

In 1995, the International Organization of Universities for Sustainable Development and Environment (Oiudsma, 2002) was formed in San Jose in Costa Rica. This organization, which is a network of IHE, aims to develop programs and research in the field of environment and sustainable development. 
The Copernicus Charter (1994), instrument created by Copernicus, was an inter-university program of cooperation for environment, and it was established by the association of European universities. The Charter expresses a collective commitment in the name of a great number of universities and represents an effort to mobilize resources of institutions for education aiming a real sustainable development. The main objectives of the program are: incorporate an environmental perspective in all university education, and to help develop pedagogical material; stimulate and coordinate the multidisciplinary integration of research projects; spread the research and the empirical discoveries widely.

In March 2000, another important event it was the meeting of ministers, from many countries of the region of the Baltic Sea at the Haga Palace in Stockholm, aiming to examine the practicality of the creation of a network of ministers, authorities and educational institutions dedicated to education for sustainable development. The second meeting took place in 2002 with participants from Denmark, Estonia, Finland, Germany, Iceland, Latvia, Lithuania, Norway, Poland, Russia and Sweden.

The objective was to examine the results that the network of ministers had achieved, related to the tasks of the first ministerial meeting at the Haga Palace in March 2000, and to adopt the Agenda 21 for education aiming sustainable development in the region of the Baltic Sea. The main decisions established - The Haga Declaration (2000) - the need to promote international cooperation concerning research on environmental topics and the creation of support for the networks which share experience and common activities in all levels. The project on the Baltic Sea is a result and may be seen as an important protagonist spreading good practices of sustainable development.

\section{The Environmental Management System in the Universities}

An effective Environmental Management System (EMS) based on NBR ISO 14001 (2007), must make the objectives and goals evident to this system, which in turn, considers the planning of actions to be fulfilled in order to eliminate or reduce significant environmental aspects, or their effects. Yet, EMS allows the definition of an evaluation process of the environmental development of companies or institutions, aiming its certification, in other words, assurance that its activities were accomplished, and services or products of international requirements were consolidated.

According to Seiffert (2007), the ISO 14001 standard directs the activities management and the environmental aspects resulting from processes, products and services of the organizations. The standard also recognizes that the organizations can be concerned with their economic and environmental efficiency. Also, ISO 14001 points to a practical and clear methodology to be followed, with the continuous improving approach of the PDCA cycle, namely: P (PLAN): define goals and methods that will allow to reach them; $\mathrm{D}(\mathrm{DO})$ : educate, train and execute the tasks of data collection, such as audits; $\mathrm{C}$ (CHECK): check the results of the executed tasks; and A (ACTION): act correctively or improve, providing with a feedback of the cycle.

When making a direct application to implant a model of environmental management in the HEI, Tauchen and Brandli (2006) develop to the Faculty of Horizontina - Brazil (FAHOR); such conception is based on the tool of PDCA, core of ISO 14000 standard, and on the particularities inherent to a university campus; Figure 4 shows the EMS model that was proposed. 


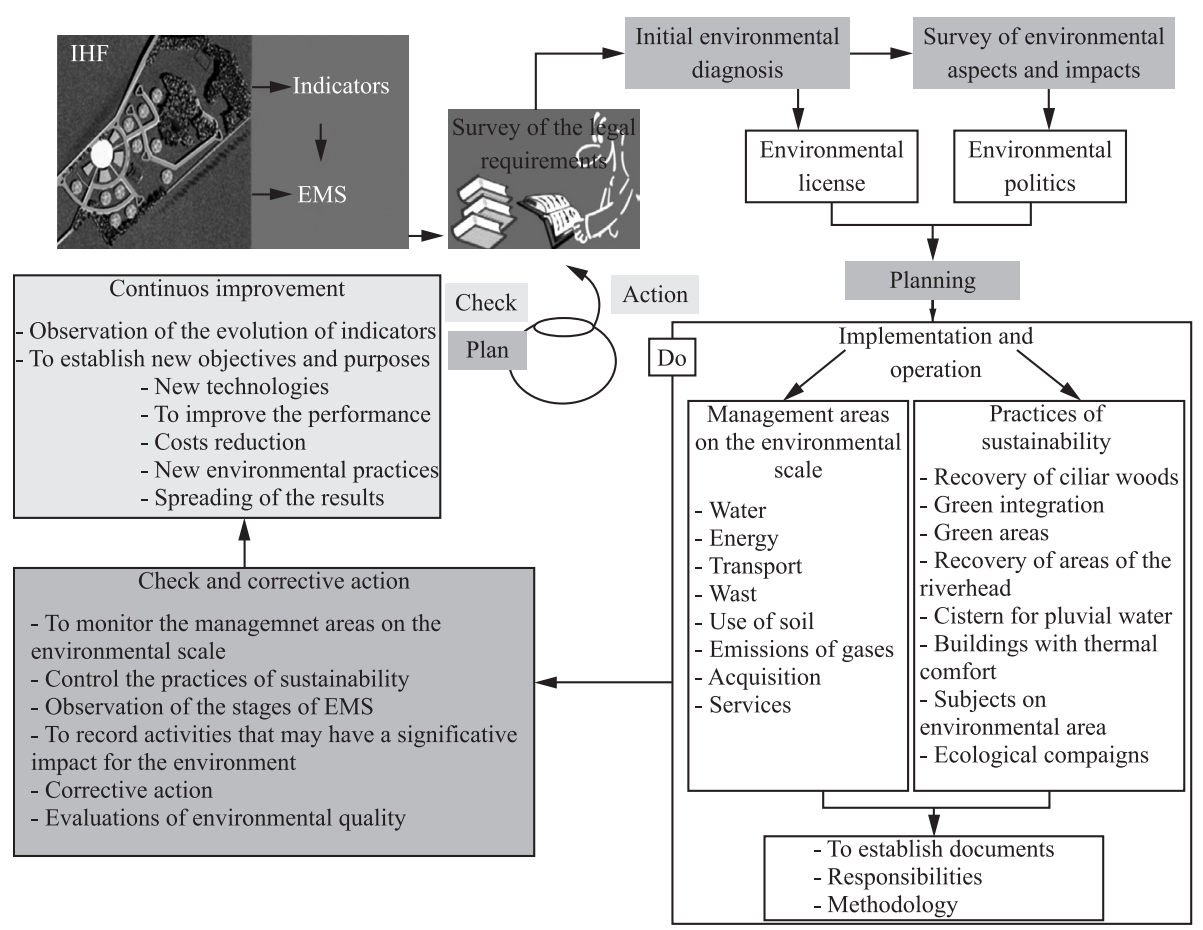

Figure 4. A model of environmental management for IHE (Tauchen and Brandli, 2006, pp. 512).

\section{Methodo}

\section{Step one}

The total of 42 universities have been researched in the United Kingdom, the United States of America, Canada, Portugal, Germany, Spain, France and New Zealand; and in Brazil there are 6 universities.

The proposed model for environmental management in an Institution of Higher Education it was based on good practices and its set-up was conceived in accordance with the rules for environmental management systems, NBR ISO 14001 (ABNT, 2004), besides the PDCA cycle.

The PDCA cycle may be described briefly:

- PLAN: to establish the objectives and processes which are necessary to achieve results, in accordance with the environmental politics of the organization;

- DO: to implement the processes;

- CHECK: to monitor and measure the processes in accordance with the environmental politics, objectives, goal, legal requirements, and to show the results;

- ACTION: to execute the actions in order to improve the performance of the environmental management system continuously. 


\section{Step two}

For evaluation of the actions at Univerity of Passo Fundo, a model of environmental management in HEI was considered, suggested by Tauchen (2006) and based on the environmental practices adopted by 42 universities reached by step one.

The University of Passo Fundo is a communitarian university (nogovernmental) that owns a multi-campuses structure, located in seven cities in the Northern Rio Grande do Sul state, Southern Brazil. Campus I, as the focus of this study, was implanted in 1968, out of the urban area according to the Anglo-Saxon location model of university centres at the surroundings of the cities. Therefore, according to Frandoloso et al. (2007) the process of growing in Passo Fundo has changed this program and at present shows its limits occupied with urbanized areas, characterized by construction of residences for middle class, commerce and services, as shown in Figure 5.

Campus I presents a surface of 341 ha with a built area of 104,347.54 $\mathrm{m}^{2}$ (data of 2007), with a growing increase of its physical area. The academic community was consisted of 19,800 students in 2007, 1,184 professors and 1,069 employees.

The survey of the sustainable initiatives of UPF, had as a basis Brandli et al. (2007), classifying in education actions, research, community and society and university life, in such a manner of comprehending all university scopes and activities.

The information was obtained with the planning department of the university, with the Science and Environmental Technology Center (CCTAM) and with the undergraduate vice-chancellors. It was analyzed undergraduate and graduate courses curricula of UPF, the institutionalized research projects and the environmental actions at the campus identified.

\section{Study Results}

\section{Initiatives and good practices of sustainability in universities}

During the process of this survey, several examples of environmental management were found within the ambit of universities. Two aspects should be emphasized concerning the results: there are isolated and precise actions; and most of the actions are directed at the situations in which the institution is already implemented and working, facilitating the actions related to the staff formation, distribution of

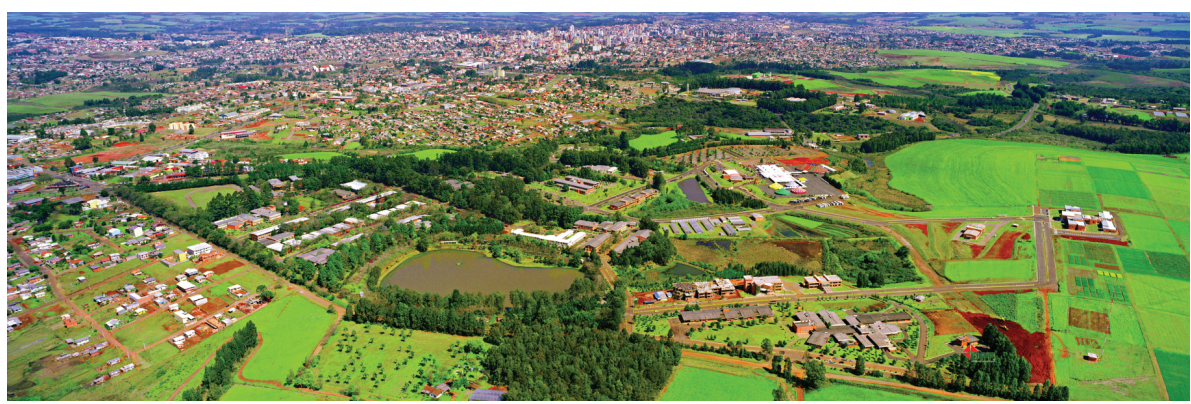

Figure 5. Campus I of UPF in Passo Fundo and urban neighborhood. 
responsibilities of the program on environmental management as well as monitoring and controlling the management indicators for the EMS.

The Tables 1-3 show briefly the sustainable actions in the researched universities. All the examples are organized according to the place of the institutions; and the marks at the lines indicate that the initiative is adopted in the IHE.

The Table 1 presents a short list of the universities which have sustainable actions in the United Kingdom (Blewitt, 2001).

The Table 2 presents a short list of the universities which have sustainable actions in Portugal, Germany, Spain, France, New Zealand and Latin America (Bonnet et al., 2002; Fouto, 2002; Careto and Venderinho, 2003; Pontificia University Javeriana, 2003; Ribeiro et al., 2005; Delgado and Vélez, 2005).

The Table 3 presents the initiatives adopted by the universities presented by Careto and Venderinho (2003), which have sustainable actions in the United States of America and Canada. include:

In the 42 IHE in total, the sustainable actions which are more significant

- Control the consumption and re-use of water and the programme of recycling waste management (about $22 \%$ of total);

- Training and sensitization of students (19\% of total);

- Environmental audit to indicate improvements whenever it is necessary and diagnosis of the impacts - direct or significant - for the environment (16\% of total).

The IHE which have the highest number of sustainable actions are the Cornwall College (United Kingdom) and the Louisville University (USA), and the number corresponds to 8 initiatives ( $18 \%$ of total).

The Figure 6 shows the initiatives in the researched universities in accordance with the implementation stages of an environmental management system, the PDCA cycle.

\section{Cases of IHE in Brazil}

The important example of a Brazilian university which implemented an Environmental Management System is the University of Vale do Rio dos Sinos (UNISINOS), and it was the first university in Latin America to have the certificate ISO 14001 due to the project Green Campus. This project aims the preservation, improvement and recuperation of the environmental quality, assuring conditions to socioeconomic development, work safety, protection to life and environmental quality (Verde Campus, 1997).

The Federal University of Santa Catarina (UFSC) is an example of attempt to implement an EMS. A Coordination of Environmental Management it was created to use teaching as a continuous search for the improvement of the relation between men and environment, therefore the community becomes a partner in this proposal to have better quality of life through the generation of knowledge (Ribeiro et al., 2005). 
Table 1. Initiatives and good practices at universities in the United Kingdom.

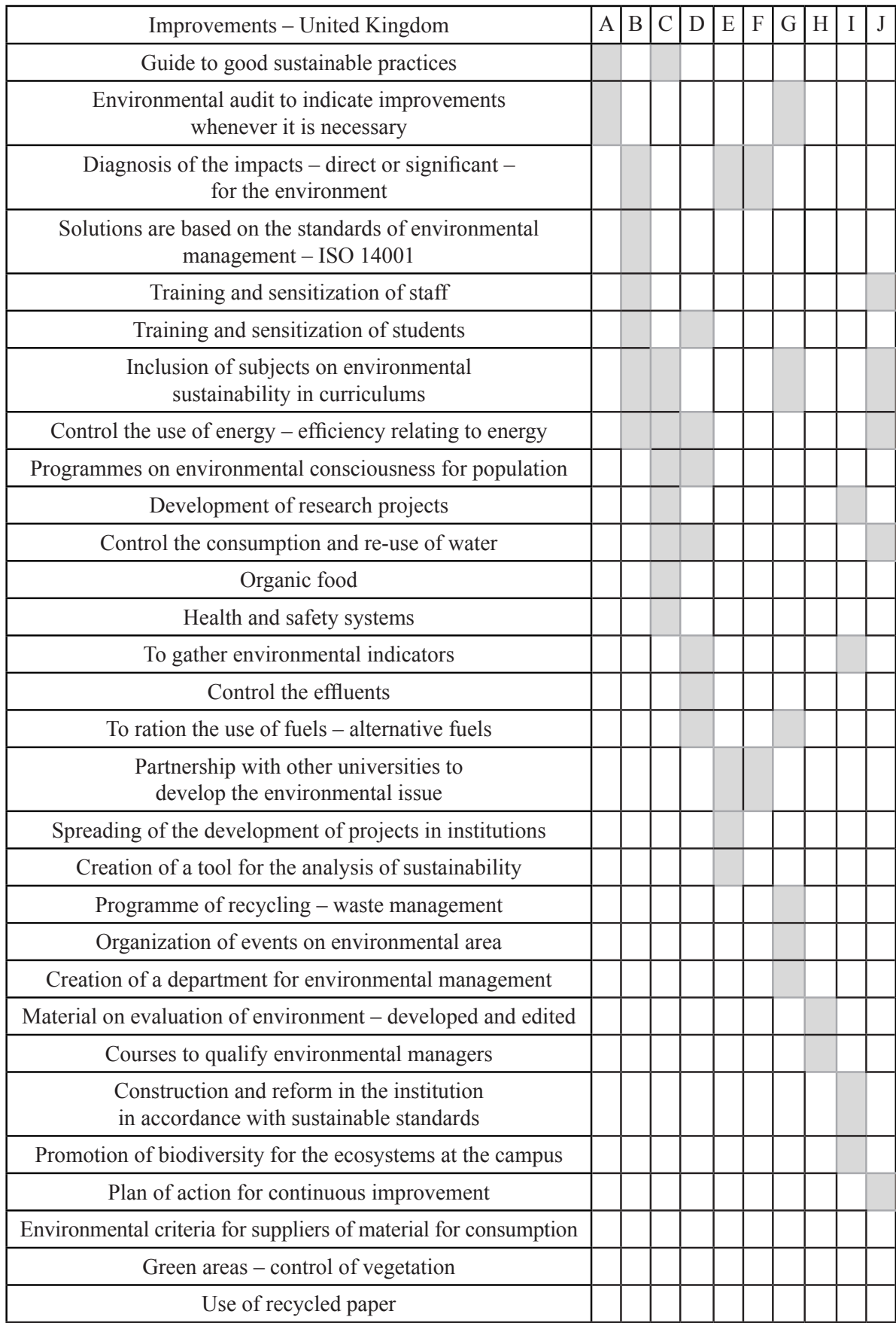

A) Bishop Burton College; B) Blackburn College; C) Cornwall College; D) Huddersfield New College; E) Southgate College, Enfield College and Capel Manor Horticultural College \& Environmental Centre; F) South West Association for Education and Training (SWAFET); G) St Helens College; H) Walford and North Shropshire College; I) Walsall College of Arts and Technology; J) Wigan and Leigh College Wigan. 
Table 2. Initiatives and good practices at universities in Europe and Latin America.

\begin{tabular}{|c|c|c|c|c|c|c|c|c|c|c|c|c|c|c|c|}
\hline $\begin{array}{c}\text { Improvements - Portugal, Germany, Spain, } \\
\text { France and New Zealand }\end{array}$ & A & $\mathrm{B}$ & $\mathrm{C}$ & $\mathrm{D}$ & E & $\mathrm{F}$ & $\mathrm{G}$ & $\mathrm{H}$ & I & $\mathrm{J}$ & $\mathrm{L}$ & $\mathrm{M}$ & $\mathrm{N}$ & $\mathrm{O}$ & $\mathrm{P}$ \\
\hline Guide to good sustainable practices & & & & & & & & & & & & & & & \\
\hline $\begin{array}{c}\text { Environmental audit to indicate improvements } \\
\text { whenever it is necessary }\end{array}$ & & & & & & & & & & & & & & & \\
\hline $\begin{array}{l}\text { Diagnosis of the impacts - direct or } \\
\text { significant - for the environment }\end{array}$ & & & & & & & & & & & & & & & \\
\hline $\begin{array}{l}\text { Solutions are based on the standards of } \\
\text { environmental management - ISO } 14001\end{array}$ & & & & & & & & & & & & & & & \\
\hline Training and sensitization of staff & & & & & & & & & & & & & & & \\
\hline Training and sensitization of students & & & & & & & & & & & & & & & \\
\hline $\begin{array}{l}\text { Inclusion of subjects on environmental } \\
\text { sustainability in curriculums }\end{array}$ & & & & & & & & & & & & & & & \\
\hline $\begin{array}{l}\text { Control the use of energy - } \\
\text { efficiency relating to energy }\end{array}$ & & & & & & & & & & & & & & & \\
\hline $\begin{array}{l}\text { Programs on environmental } \\
\text { consciousness for population }\end{array}$ & & & & & & & & & & & & & & & \\
\hline Development of research projects & & & & & & & & & & & & & & & \\
\hline Control the consumption and re-use of water & & & & & & & & & & & & & & & \\
\hline Organic food & & & & & & & & & & & & & & & \\
\hline Health and safety systems & & & & & & & & & & & & & & & \\
\hline To gather environmental indicators & & & & & & & & & & & & & & & \\
\hline Control the effluents & & & & & & & & & & & & & & & \\
\hline To ration the use of fuels - alternative fuels & & & & & & & & & & & & & & & \\
\hline $\begin{array}{l}\text { Partnership with other universities } \\
\text { to develop the environmental issue }\end{array}$ & & & & & & & & & & & & & & & \\
\hline $\begin{array}{l}\text { Spreading of the development of } \\
\text { projects in institutions }\end{array}$ & & & & & & & & & & & & & & & \\
\hline $\begin{array}{c}\text { Creation of a tool for the analysis of } \\
\text { sustainability }\end{array}$ & & & & & & & & & & & & & & & \\
\hline Programme of recycling - waste management & & & & & & & & & & & & & & & \\
\hline Organization of events on environmental area & & & & & & & & & & & & & & & \\
\hline $\begin{array}{c}\text { Creation of a department for environmental } \\
\text { management }\end{array}$ & & & & & & & & & & & & & & & \\
\hline $\begin{array}{c}\text { Material on evaluation of environment - } \\
\text { developed and edited }\end{array}$ & & & & & & & & & & & & & & & \\
\hline Courses to qualify environmental managers & & & & & & & & & & & & & & & \\
\hline
\end{tabular}

A) University of Algarve (Portugal); B) University of Aveiro (Portugal); C) Technical University of Lisbon (Portugal); D) New University of Lisbon (Portugal); E) University of Zittau Gorlitz (Germany);F) Autonomous University of Barcelona (Spain); G) Autonomous University of Madrid (Spain); H University of Granada (Spain); I) University of Bordeaux (France); J) University of Auckland (New Zealand); L) National Autonomous University of Mexico(Mexico); M) Pontificia University Javeriana (Colombia); N) Externado University of Colombia (Colombia); O) National University of Colombia (Colombia); P) University Del Valle (Colombia). 
Table 2. Continued....

\begin{tabular}{|c|c|c|c|c|c|c|c|c|c|c|c|c|c|c|c|}
\hline $\begin{array}{c}\text { Improvements - Portugal, Germany, Spain, } \\
\text { France and New Zealand }\end{array}$ & A & B & C & D & E & F & G & H & I & J & L & M & N & O & P \\
\hline $\begin{array}{c}\text { Construction and reform in the institution in } \\
\text { accordance with sustainable standards }\end{array}$ & & & & & & & & & & & & & & & \\
\hline $\begin{array}{c}\text { Promotion of biodiversity for } \\
\text { the ecosystems at the campus }\end{array}$ & & & & & & & & & & & & & & \\
\hline Plan of action for continuous improvement & & & & & & & & & & & & & & \\
\hline $\begin{array}{c}\text { Environmental criteria for } \\
\text { suppliers of material for consumption }\end{array}$ & & & & & & & & & & & & & & \\
\hline Green areas - control of vegetation & & & & & & & & & & & & & & \\
\hline Use of recycled paper & & & & & & & & & & & & & & & \\
\hline
\end{tabular}

A) University of Algarve (Portugal); B) University of Aveiro (Portugal); C) Technical University of Lisbon (Portugal); D) New University of Lisbon (Portugal); E) University of Zittau Gorlitz (Germany);F) Autonomous University of Barcelona (Spain); G) Autonomous University of Madrid (Spain); H University of Granada (Spain); I) University of Bordeaux (France); J) University of Auckland (New Zealand); L) National Autonomous University of Mexico(Mexico); M) Pontificia University Javeriana (Colombia); N) Externado University of Colombia (Colombia); O) National University of Colombia (Colombia); P) University Del Valle (Colombia).

Table 3. Initiatives and good practices at universities in the United States of America and Canada.

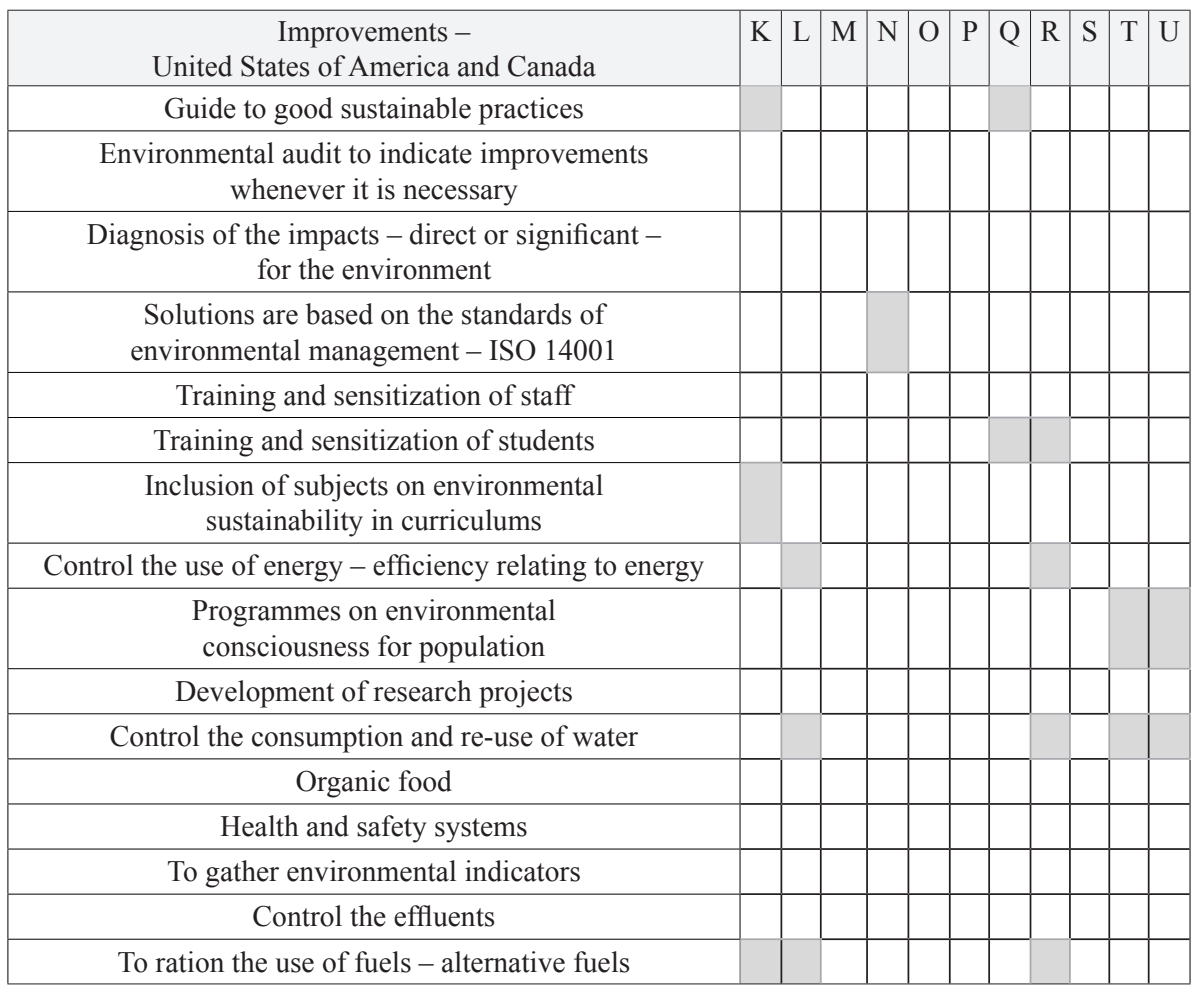

K) Vermont University (USA); L) Burlington University (USA); M) Michigan University (USA); N) University of South Carolina (USA); O) University of Missouri-Roll (USA); P) Emory University (USA); Q) Carnegie Mellon University (USA); R) Louisville University (USA); S) Middlebury College (USA); T) British University (Canada); U) Harvard University (USA). 
Table 3. Continued...

\begin{tabular}{|c|c|c|c|c|c|c|c|c|c|c|c|}
\hline $\begin{array}{c}\text { Improvements - } \\
\text { United States of America and Canada }\end{array}$ & $\mathrm{K}$ & $\mathrm{L}$ & M & $\mathrm{N}$ & $\mathrm{O}$ & $\mathrm{P}$ & $Q$ & $\mathrm{R}$ & & & $\mathrm{U}$ \\
\hline $\begin{array}{l}\text { Partnership with other universities } \\
\text { to develop the environmental issue }\end{array}$ & & & & & & & & & & & \\
\hline Spreading of the development of projects in institutions & & & & & & & & & & & \\
\hline Creation of a tool for the analysis of sustainability & & & & & & & & & & & \\
\hline Programme of recycling - waste management & & & & & & & & & & & \\
\hline Organization of events on environmental area & & & & & & & & & & & \\
\hline Creation of a department for environmental management & & & & & & & & & & & \\
\hline $\begin{array}{c}\text { Material on evaluation of environment - } \\
\text { developed and edited }\end{array}$ & & & & & & & & & & & \\
\hline Courses to qualify environmental managers & & & & & & & & & & & \\
\hline $\begin{array}{l}\text { Construction and reform in the institution } \\
\text { in accordance with sustainable standards }\end{array}$ & & & & & & & & & & & \\
\hline Promotion of biodiversity for the ecosystems at the campus & & & & & & & & & & & \\
\hline Plan of action for continuous improvement & & & & & & & & & & & \\
\hline $\begin{array}{l}\text { Environmental criteria for suppliers } \\
\text { of material for consumption }\end{array}$ & & & & & & & & & & & \\
\hline Green areas - control of vegetation & & & & & & & & & & & \\
\hline Use of recycled paper & & & & & & & & & & & \\
\hline
\end{tabular}

K) Vermont University (USA); L) Burlington University (USA); M) Michigan University (USA); N) University of South Carolina (USA); O) University of Missouri-Roll (USA); P) Emory University (USA); Q) Carnegie Mellon University (USA); R) Louisville University (USA); S) Middlebury College (USA); T) British University (Canada); U) Harvard University (USA).

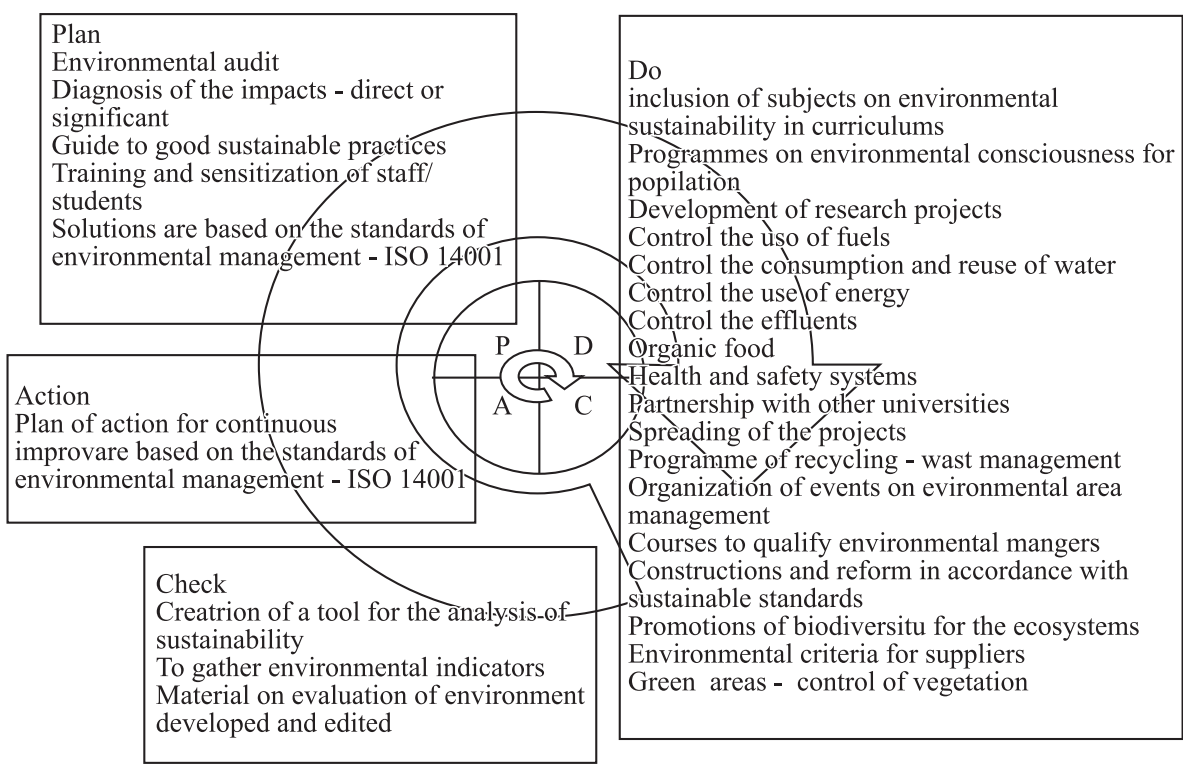

Figure 6. Initiatives and good practices at universities in accordance with PDCA (Tauchen and Brandli, 2006, pp. 512). 
In the State of Santa Catarina, it also appears the Regional University of Blumenau (FURB). This institution marked a posture of environmentally conscious when created the Committee for Implementation of EMS in March 1998, with representatives of all university community, aiming to identify clearly their environmental problems, in order to establish a plan of continuous improvement to attenuate or eliminate these problems. This committee, in accordance with the rules of ISO 14001, elaborated the Environmental Politics of FURB and started the Environmental Plan, culminating in the creation of the EMS of the university in 1999 (Butzke et al., 2001).

According to Ribeiro et al. (2005), the Federal University of Rio Grande do Sul (UFRGS) also has been struggling to implement an EMS. Initially, a diagnosis of the resultant waste it was made as well as its different destinations at the university units. At the Engineering and Administration Faculties, students planned a system of Urban Solid Waste Management (GRSU), and the groups did a survey of the resultant waste. Currently, possible actions are being implemented to reduce the consumption of energy and water.

At the University of São Paulo (USP) there are the Programme of Rational Use of Energy (PURE), Programme of Rational Use of Water (PURA) and the USP Programme of Recycling.

At the University of Passo Fundo (UPF) there are various actions in the areas related to university infrastructure, research, teaching and extension. Nevertheless, there is not a structured EMS. There are some actions to highlight: sewage treatment system; selective waste collection; make good use of the rainwater; and own generator (Brandli et al., 2007; Frandoloso et al., 2008).

The institutions presented above are precise examples in the universe of IHE in Brazil.

\section{Environmental Practices Developed in the University of Passo Fundo}

\section{University Life}

Regarding the management and maintenance of the physical structure of the campus, buildings and installations, the following actions were identified: Centre);

1) Reorganization of CCTAM (Science and Environmental Technology

2) Environmental audit to indicate improvements where necessary, with the elaboration of an Environmental Report, according to procedures of FEPAM (State Foundation of Environmental Protection), in 2007, thus resulting in the Operation License, with the objective of being environmentally correct and adapted to the legislation in force;

3) Diagnosis of the direct or significant impacts to the environment;

4) Production of Landscape catalogue and interpretation of Campus I;

5) Audits development to evaluate the thermal and energetic performance of buildings of the Faculty of Engineering and Architecture (2007); 
6) Controlling of energy use, through implantation of own electrical energy production with the use of diesel, as well as the project for installation of a computerized system of demand and energy consumption monitoring, in order to evaluate the energetic performance in every educational institution or building;

7) Existent Lighting equipment replaced by lamps and reactors with better energetic efficiency;

8) Control of consumption and reuse of water for toilets, with stormwater recollection at CETEC - FEAR;

people;

9) Anaerobic system to sewage treatment with capacity for 18 thousand

10) Collection and separation of recyclable residues, since 2003, through the construction of the Central of Residues, being the dry solid urban waste donated to the Citizenship Committee Against Starvation of Passo Fundo;

1)1Organic residues resulting from gardening and prune are used in production of composting; company;

12) Storage of fluorescent bulbs to direct recycling through a specialized

13) Specialized collection of residues of the health area, to direct incineration through a specialized company;

14) Laboratories make the separation of chemical residues to send them to a specialized company, as well as storage of batteries and piles of X-ray fixers and developers;

15) Adoption of environmental criteria with suppliers of consumption materials, sustainable practice, that has as an implemented action the use of recyclable paper throughout the campus.

\section{Research}

Regarding the researches developed at UPF, it can be observed that:

1) From 335 projects in progress until July 2007, 44 institutionalized projects that approach this theme are related to the environment and the environmental planning, with studies on habitability of buildings, management of natural resources at the Campus, planning of physical structures and of sustainable infrastructure for reuse of pluvial water, among others.

\section{Education}

Regarding the actions related to education, in graduation as well as in postgraduation levels, it can be highlighted that:

1) The University has been improved the "environmentalization" or "greening" the curriculum in most courses, through inclusion of environmental sustainability subjects in the courses. Another practice is the training for sensitization of the students that happens during the classes or in an informal manner; 
2) The existence of graduation course in Environmental Engineering, Post-graduation course in Environmental Technology and Master in Engineering, Infrastructure and Environment is highlighted.

\section{Community and society}

Regarding the community and society, initiatives related to the universitycommunity relationship can be seen, by means of promotion of actions that lead to environmental education of the society. Yet, the promotion of scientific events about environmental theme also takes place, such as:

1) "Projeto Sala Verde Itinerante", with the objective of to integrate environmental education programs that each entity develops and intends to extend the proposal of environmental perception and digital inclusion, contributing with the formation of environmental educators;

2) "Projeto Ecologia no Campus", which the objective was to improve a culture, peace and integration moment of the community with the nature at the campus of the University of Passo Fundo, socializing with experiences in workshops on environmental education;

3) "Projeto Charão" led by the Environment Friends Association, program of environmental education for preservation of wild life, which main focus is the preservation of the Forest ecosystem with Araucária, that acts since 1991 in Rio Grande do Sul and in Santa Catarina. Papagaio-charão, a native specimen of regional bird, is the main symbol of the program;

3) "Projeto Domingo Animal", commenced in April 2008, is a project of environmental education that occurs once a month, and at each edition promotes visiting to the animals and activities of integration and amusement, approaching, on every Sunday, a different species among the animals of UPF Zoo;

4) Environmental Video Show of Passo Fundo, a space for communication, articulation and integration of institutions and people, for discussions and actions of environmental education;

5) UPF was invited to make part of an international project about sustainability of food production. The objective is to search for alternatives that guarantee the sustainability of food production before some perspectives of population increase;

6) The first workshop entitled "A Floresta em Ambientes Fluviais" at the I Simpósio de Gestão Integrada em Recursos Hídricos was presented;

7) Organization of the Regional and State Forum of Biodiversity;

8) Co-organization of the VIII Municipal Meeting of Evaluation of Environmental Actions and I Youth Environmental Encounter;

9) Organization of I ELAUS - Latin-American meeting of Sustainable Universities, with the Universidad Nacional de Córdoba, Argentina, and the University of São Paulo, Brazil, in order to promote the discussion of the theme in the university scope and encourage the formation of inter-institutional cooperation nets. This event, 
developed in September 2008, aimed to discuss the issues to present at EMSU2008, in Barcelona - Spain, occurred in October 2008.

\section{Relationship of practices with the Environmental Management System}

The logic of the cycle PDCA directed the production of ISO 14001 in the implantation of the Environmental Management System, basing on the direction of the continuous improvement. For this reason, the classification of the environmental actions of UPF in the stages of PDCA cycle can indicate the position of the university regarding the systemic environmental management. The action previously presented was numbered and classified according to Figure 7.

UPF has many practices that can be translated as sustainable actions; therefore, these practices are, in such a general manner, isolated actions which do not consider all courses and colleges of the campus, confirming the profile of the researched universities in the survey of Tauchen and Brandli (2006)

Observing PDCA cycle, the actions are mostly in the stage DO, however, this stage considers other aspects that do not appear in the initiatives of UPF. The university has an important action which is the environmentalization of its undergraduate courses curriculum and many studies being produced with the sustainability theme. Concerning university life, it is noteworthy to highlight the selective collection of waste and the discard of them, respecting the class and the legal demand. The control of energy and water consumption are also actions already implanted, therefore, the use of rain water should be more explored throughout the campus, for several use, specially for cleaning and preservation of green areas.

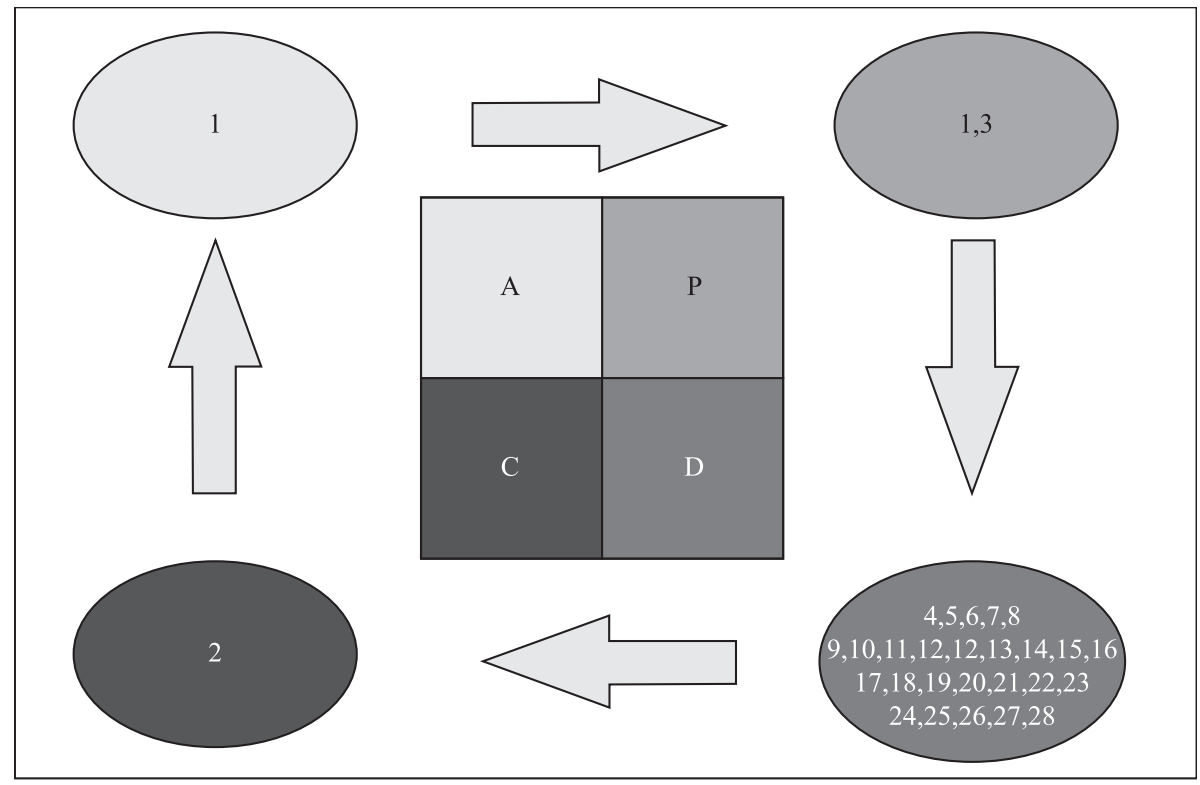

Figure 7. Relationship of environmental practices of UPF and PDCA cycle. 


\section{Guidelines to the Process of Environmental Management of UPF}

Once implicitly included in the Social Responsibility term of UPF (2005) the lack of an environmental management to the campus, which has defined a responsible staff, which develops an environmental policy, a critical analysis of improvement and current conditions, and a management based on the continuous improvement is clear.

The environmental issue in universities must include analysis responsible and detailed of each flow in a campus, being based in physical buildings. However, also allowing that economic issues are considered; include the evaluation of consistent indicators; involve the detailed study of these indicators in order to understand and estimate the improvement potential of the system; to be used as continuous improvement of environmental parameters of the system according to the remarkable environmental commitment that the institutions must demonstrate.

The first step for implementation of the EMS is the definition of the Environmental Policies of UPF, which will direct other stages of the system. Other important aspect is to improving the partnership and networking groups with other universities to develop the environmental issue, beginning with the proposal of the shared organization of ELAUS2008, involving several HEI.

Making a decision of adopting a systemic approach to the environmental management is a great step. It means to become pro-active instead of reactive, to define and to fulfil objectives, and to implement an environmental policy, which will direct all HEI in environmental themes. This commitment must come from the high administration, in this case, from the chancellors, directors, and faculty and course coordinators.

The implantation of EMS implies the creation and ability of support mechanisms to environmental polices, objectives and goals, and for this reason, investments are necessary, not only financial ones, but human capital.

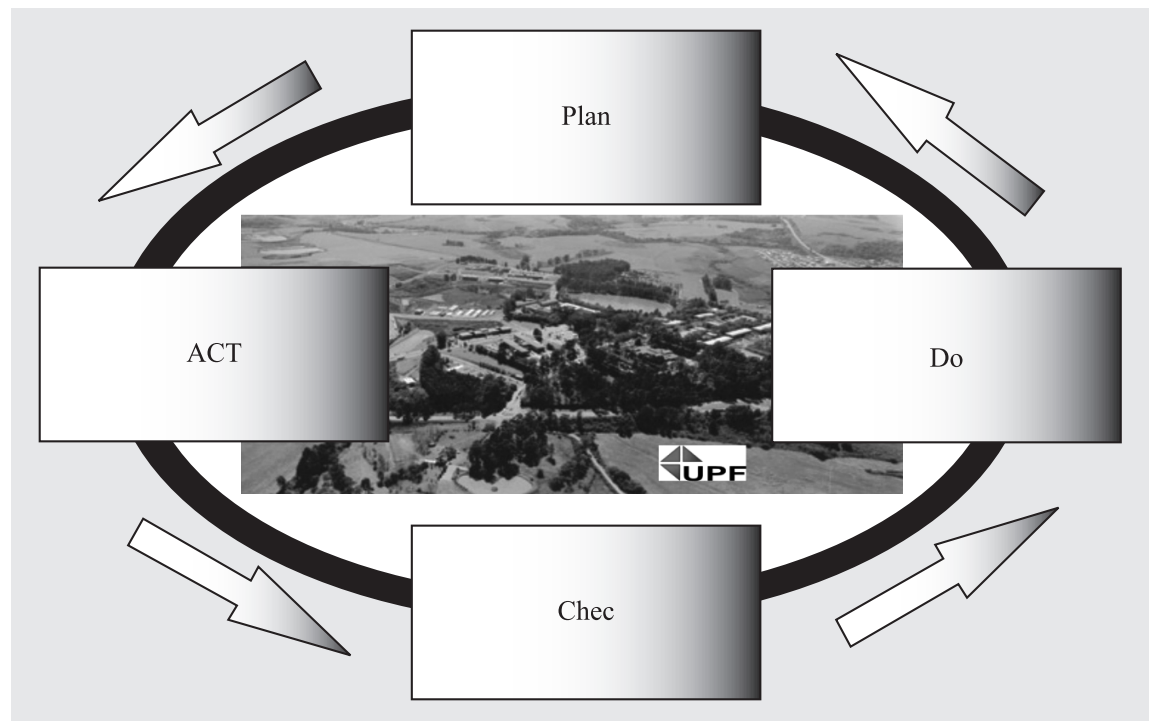

Figure 8. Guidelines for employment of EMS at UPF. 
Chart 1. Synthesis of the action for implementation at UPF.

\begin{tabular}{|c|c|}
\hline PDCA & Actions \\
\hline P-Plan & $\begin{array}{l}\text { Identification and evaluation of environmental aspects potential impacts; } \\
\text { Identification of legal requirements inherent to activities developed in the campus; } \\
\text { Definition of objectives and goals according to previous items; }\end{array}$ \\
\hline D-Do & $\begin{array}{l}\text { Creation of department for environmental management - definition of responsibilities; } \\
\text { Training and sensitization of employees; professors and students; } \\
\text { Internal and external communication in the campus; } \\
\text { Documentation of actions/procedures and control of this documentation; } \\
\text { Preparation and reply to emergencies; } \\
\text { Environmental awareness programs directed to population; } \\
\text { Incentive to use of organic feed; } \\
\text { Rationalization of fuel use - alternative fuel; } \\
\text { Constructions and renovation in the institution following sustainable patterns; } \\
\text { Promotion of biodiversity of ecosystems in the campus; } \\
\text { Guide with good sustainable practice; }\end{array}$ \\
\hline C-Check & $\begin{array}{c}\text { Collection and monitoring of environmental indicators; } \\
\text { Definition of corrective and preventive actions; } \\
\text { Control of records of monitored data; } \\
\text { Development and edition of materials of environmental evaluation; }\end{array}$ \\
\hline A-Act & $\begin{array}{l}\text { Creation of tool for sustainability analysis; } \\
\text { Solutions based on the pattern of environmental management of ISO 14001; } \\
\text { Action plan for continuous improvement. }\end{array}$ \\
\hline
\end{tabular}

So that the EMS is consolidated, it is necessary that the stages of checking and critical analysis are accomplished and that there is a continuous improvement in the proposition and reach of everyone.

Chart 1 shows a synthesis of the action that could be implemented at UPF, according to the stages of cycle PDCA (Figure 8).

\section{Conclusions}

The environmental responsibility of the High Education Institutions (HEI) begins with the inclusion of sustainable principles, among them the environmental management of all academic and administrative activities, in order to foment the application of good practices of the environmental management and to insert them in the concept of "eco-campus". In this sense, the discussion of concrete practices already adopted in the universities is relevant, in this case the University of Passo Fundo, located in the Southern Brazil, as well as to suggest strategies for inclusion of other practices not consolidated yet and/or considered. 
Many initiatives of action environmentally correct have been adopted by HEI, therefore, in their great majority, are isolated and do not consider a systemic, extended vision. This is also the case of UPF, as the data surveyed in this paper demonstrate, since the definition of a consistent Environmental Policy is essential.

This initiative panorama deserves the effort of several HEI, and shows their increasing concern and commitment, pointing for a success way on behalf of education for the sustainable development.

In general terms, the environmental management in universities must include responsible and detailed analyses of each flow in a campus, base on physical buildings, therefore, also allowing that economic matters are considered; include the evaluation of consistent indicators; involve the detailed study of these indicators in order to understand and estimate the system improvement potential; serve as continuous improvement of the environmental parameters of the system, according to the exemplary environmental commitment that the institution need to demonstrate.

Another aspect to be pointed out is that this methodology could have its reproducibility in other universities, not as a model, but in such a manner that its contexts of insertion and specific features be properly reviewed.

Finally, the implementation and feedback of an EMS can effectively contribute to involve all agents of the academic community in social transformations towards sustainability, reinforcing the concepts presented in the course of this work related to the role of the University in the formation of professionals responsible and being committed with these processes.

\section{Acknowledgments}

To the University of Passo Fundo (UPF), for its collaboration and institutional support for the accomplishment of this research, as well as to CNPQ and UPF for the scholarship of basic scientific research to students involved in this study. To CNPQ for the financial support.

\section{References}

Associação Brasileira de Normas Técnicas - ABNT (2004) NBR ISO 14001. Sistemas de gestão ambiental: Especificação e diretrizes para uso. Rio de Janeiro: ABNT. (in Portuguese)

Almeida, J.R.; Bastos, A.C.S.; Malheiros, T.M. and Silva, D.M. (2008) Política e planejamento ambiental. Rio de Janeiro: Thex Editora. (in Portuguese)

Blewitt, J. (2001) Good practice in sustainable development education: evaluation report and good practice guide. London: Learning and Skills Council.

Bonnet, J.F.; Devel, C.; Faucher, P. and Roturier, J. (2002) Analysis of electricity and water end-uses in university campuses: case-study of the University of Bordeaux in the framework of the Ecocampus European Collaboration. Journal of Cleaner Production, Vol. 10, No.1, pp. 13-24. http://dx.doi.org/10.1016/S0959-6526(01)00018-X

Brandli, L.L.; Frandoloso, M.A.L.; Rodrigues, F.B. and Ceconello, V. (2008) A sustentabilidade ambiental na infra-estrutura de um campus universitário: ações, in: Encontro Nacional de Tecnologia do Ambiente Construído. (in Portuguese)

Brandli, L.L.; Frandoloso, M.A.L.; Tauchen, J.; Rodrigues, F.B. and Ceconello, V. (2007) Gestão ambiental em instituições de ensino superior: uma abordagem às práticas de 
sustentabilidade da Universidade de Passo Fundo. OLAM - Ciência \& Tecnologia, Vol. 7, No. 3, pp. 24-44. (in Portuguese)

Butzke, I.C.; Perira, G.R. and Noebauer, D. (2001) Sugestão de Indicadores para avaliação do desempenho das atividades educativas do Sistema de Gestão Ambiental - SGA da Universidade Regional de Blumenau - FURB, in: I Congresso de Educação Ambiental na Área do Mar de Dentro, Rio Grande. (in Portuguese)

Careto, H. and Vendeirinho, R.S. (2003) Sistemas de gestão ambiental em universidades: caso do Instituto Superior Técnico de Portugal. Relatório Final de Curso. Available: http://meteo.ist.utl.pt/ jjdd/LEAMB/LEAmb\%20TFC\%20site\%20v1/20022003/ HCareto_RVendeirinho\% 20artigo.pdf. Access: 10th May, 2005. (in Portuguese)

Delgado, C.C.J. and Vélez, C.Q. (2005) Sistema de gestión ambiental universitária: caso Politécnico Gran Colombiano. Available: http://ecnam.udistrital.edu.co/pdf/r/edge02/ node03.pdf. Access: 9th December, 2005. (in Spanish)

Ferrer-Balas, D. (2001) Global environmental planning at the Technical University of Catalonia. International Journal of Sustainability in Higher Education, Vol. 5, No.1, pp. 48-62. http://dx.doi.org/10.1108/14676370410512580

Fouto, A.R.F. (2002) O papel das universidades rumo ao desenvolvimento sustentável: das relações internacionais às práticas locais. Dissertação. Programa de Pós-Graduação em Gestão e Políticas Ambientais Relações Internacionais do Ambiente, Faculdade de Ciências e Tecnologia da Universidade Nova de Lisboa, Lisboa, Portugal. (in Portuguese)

Frandoloso, M.; Brandli, L.L.; Rodrigues, F.B. and Tauchen, J. (2008) Avaliação das práticas de sustentabilidade na Universidade de Passo Fundo - RS: diretrizes para a continuidade do processo de gestão ambiental, in: XIII Seminário de la Asociación de los Investigadores y Estudiantes Brasileños en Cataluña; Barcelona - Spain, pp. 241-250. (in Portuguese)

Frandoloso, M.; Cunha, E.G.; Brandli, L.L.; Rodrigues, F.B.; Rostirolla, J.A.; Turella, L.; Negri, L. and Marchiori, T. (2007) Sustainability and natural resources uses at a South Brazilian university: proposing an environmental plan to University of Passo Fundo. Portugal SB07: Sustainable construction: materials and practices, Vol. 1, No. 2, pp. 139-146. (in Portuguese)

Halac, R.; Schiller, S. and Venturini, E. (2005) Sustainable universities: new knowledge and innovative actions, in: World Sustainable Building Conference, pp. 2316-2322.

International Association of Universities (1993) Educations for Sustainable Development. Available: http://portal.unesco.org/education. Access: 20th November, 2005.

Kraemer, M.E.P. (2004) Gestão ambiental: um enfoque no desenvolvimento sustentável. Available: http://www.gestaoambiental.com.br/kraemer.php. Access: 28th November, 2005. (in Portuguese)

Leal Filho, W. (2000) Sustainability and university life. Frankfurt: Peter Lang. Vol. 5, 270p. Series: Umweltbildung, Umweltkommunikation und Nachhaltigkeit Second edition.

Mayor, F. (1998) Preparar um futuro viável: ensino superior e desenvolvimento sustentável, in: Conferência mundial sobre o ensino superio: Tendências de educação superior para o século XXI. (in Portuguese)

Organización Internacional de Universidades por el Desarrollo Sostenible y Medio Ambiente - Oiudsma (2002) Available: http://www.ugr.es/ oiudsma/Welcome.htm. Access: 10th April, 2005. (in Spanish)

Pontifica Universidad Javeriana (2003) Sistema de Gestión ambiental. Available: http://www.javeriana.edu.co/facultades/fear/institutos/inicio.htm. Acess: 8th August 2005. (in Portuguese) 
Ribeiro, A.L.; Bressan, L.W.; Ribeiro, L.A.; Lemos, M.F. ; Dutra, C. and Nascimento, L.F. (2005) Avaliação de barreiras para implementação de um sistema de gestão ambiental na UFRGS, in: XXV Encontro Nacional de Engenharia de Produção. (in Portuguese)

Seiffert, M. E. B. (2007) ISO 14001 sistemas de gestão ambiental: implantação objetiva e econômica. São Paulo: Atlas. (in Portuguese)

Tauchen, J. (2006) Um modelo de gestão ambiental para implantação em Instituições de Ensino Superior. Dissertação. Programa de Pós-Graduação em Engenharia, Universidade de Passo Fundo, Passo Fundo. (in Portuguese)

Tauchen J. and Brandli, L.L. (2006) A Gestão ambiental em instituições de ensino superior: modelo para implantação em campus universitário. Gestão \& Produção, Vol. 13, No. 3, pp. 503-515. (in Portuguese)

The Haga Declaration (2000) Haga

The Halifax Declaration (1991) Halifax.

The Kyoto Declaration (1993) Kyoto.

The Swansea Declaration (1993) Swansea.

University Leaders for a Sustainable Future - ULSF (1990) Declaración de Talloires: declaración de líderes de universidades para un futuro sostenible. (in Spanish)

UNESCO (2005) Education for Sustainable Development. Draft International Implementation Scheme for the UN Decade of Education for Sustainable Development (20052014). 53p.

Universidad Autónoma de Madrid (1997) Ecocampus. Available: www.uam.es/ servicios/ecocampus/especifica/proyecto.html. Access: 12th June, 2005. (in Spanish)

Universidade de Passo Fundo - UPF (2005) Políticas de Responsabilidade Social da Universidade de Passo Fundo. (in Portuguese)

University Charter For Sustainable Development (1994) Copernicus. Available: http://www.iisd.org/educate/declarat/coper.htm. Access: 28th November, 2005.

Unisinos (1997) Verde Campus. Available: <http://www.unisinos.br/verdecampus/>. Access: 12th December, 2005.

Viebahn, P. (2002) An environmental management model for universities: from environmental guidelines to staff involvement. Journal of Cleaner Production, Vol. 10, No. 1, pp.3-12. http://dx.doi.org/10.1016/S0959-6526(01)00017-8

Zitzke, V.A. (2002) Educação Ambiental e Ecodesenvolvimento. Revista Eletrônica do Mestrado em Educação Ambiental. Vol. 9, 2002. Avaible: http://www.fisica.furg.br/mea/remea/ vo19/a13art16.pdf. Access: 27th May, 2006. (in Portuguese)

\section{Biography}

Luciana Londero Brandli is Professor Adjunto III in the Architecture and Engineering Faculty at the Passo Fundo University. She is doctor in production engineering. She is teaching and researching in Pos-graduation of Infrastructure and Environment Program.

Contact: brandli@upf.br

Marcos Antonio Leite Frandoloso is Professor Adjunto II in the Architecture and Engineering Faculty at the Passo Fundo University. Actually is doing doctoring at Universitat Politècnica de Cataluña, Barcelona, Spanish.

Contact: frandoloso@upf.br 
Joel Tauchen is Professor at the Horizontina Faculty. He received his degrees in master in 2006 in the Pos-graduation of Infrastructure and Environment Program at the Passo Fundo University.

Contact: tauchenjoel@cfjl.com.br

\section{Article Info:}

Received: April, 2010

Accepted: June, 2011 